\title{
PENGEMBANGAN RENCANA PELAKSANAAN PEMBELAJARAN (RPP) TAHAP AWAL PEMBELAJARAN BAHASA JEPANG BERBASIS STANDAR PROSES KURIKULUM 2013 REVISI UNTUK SEKOLAH DASAR DI BALI
}

\author{
N.N. Sukni ${ }^{1}$, D.M.S. Mardani ${ }^{2}$, I.W. Sadyana ${ }^{3}$ \\ ${ }^{123}$ Jurusan Bahasa Asing, Universitas Pendidikan Ganesha, Singaraja \\ Email: ni.nengah.sukni@undiksha.ac.id, desak.mardani@undiksha.ac.id,
}

wayan.sadyana@undiksha.ac.id

\begin{abstract}
Abstrak
Penelitian ini bertujuan untuk mengembangkan rencana pelaksanaan pembelajaran (RPP) tahap awal bahasa Jepang berbasis standar proses Kurikulum 2013 Revisi yang sesuai untuk SD di Bali. Penelitian ini menggunakan model pengembangan four-D dari Thiagarajan yang dimodifikasi agar sesuai dengan pengembangan RPP. Model pengembangan four-D dalam penelitian hanya dilakukan 3 tahap yaitu define, design, dan develop. Sedangkan tahap disseminate tidak dilakukan karena keterbatasan waktu. Subjek dalam penelitian ini adalah guru pengajar bahasa Jepang di SD. Data dikumpulkan menggunakan angket yang kemudian dianalisis secara deskriptif kualitatif. Hasil dari penelitian ini adalah (1) RPP ini terdiri dari bab 1 sampai bab 15 (2) dalam RPP memuat keterampilan 4C (Communication, Collaboration, Critical Thinking, dan Creativity), HOTS (Higher Order Thinking Skills), PPK (Penguatan Pendidikan Karakter), dan literasi, (3) kegiatan dalam RPP memuat banyak permainan, (4) berdasarkan uji ahli dan uji coba menunjukkan hasil sangat layak.
\end{abstract}

Kata kunci: RPP, Kurikulum 2013 Revisi, SD.

\section{要旨}

本研究の目的はバリ島の小学校に適した改訂された2013年カリキュラムプロセス基準に基づいて日本 語の初期学習実施計画を開発することである。本研究は学習実施計画の開発に合わせて、変更された チアガラジャンの4D設計モデル「定義設計開発」を使用して開発された。本研究における4D設計モ デルは、定義、設計、開発の3つの段階しか実行されない。時間の制約のため、普及の段階は実行さ れなかった。調査協力者はバリ島の小学校の日本語の教師である。調査方法はアンケートである。こ のデータを定性的記述法により分析した。分析した結果、1）この学習実施計画は第 1 課から第 15 課までである、2）学習実施計画には4C教育「コミュニケーション、コラボレーション、クリティカ ルシンキング、クリエイティビティ」、HOTS教育「高等思考スキル」、キャラクター教育の強化、 および識字能力が含まれている、3）学習実施計画の活動の中で、多くのゲームを含まれている、4 ）専門家のテストや試練に基づいて、この学習実施計画は非常に適切で使用寸ることができるだと示 している。

キーワード: 学習実施計画、改訂された2013年カリキュラム、小学校

\section{Pendahuluan}

Dengan perkembangan ilmu pengetahuan dan teknologi internasional yang sangat pesat, bahasa menjadi sangat penting untuk dipelajari. Salah satu bahasa asing yang dipelajari selain bahasa Inggris adalah bahasa Jepang. Berdasarkan survei yang dilakukan The Japan Foundation pada tahun 2015, Indonesia menempati urutan kedua sebagai pembelajar bahasa Jepang terbanyak setelah Tiongkok. Jumlah pembelajar bahasa Jepang di Indonesia mencapai 745.125 pembelajar (Japan Foundation, 2017). Pembelajar bahasa Jepang di Indonesia tidak hanya diminati oleh kalangan SMA/SMK, namun juga diminati oleh kalangan anak SD. Hal ini dilihat dari jumlah pembelajar bahasa Jepang pada tingkat SD mencapai 6.504 orang, dengan perbandingan jumlah pembelajar yang mengikuti pembelajaran bahasa Jepang termasuk kulikuler lebih banyak daripada pembelajar yang mengikuti bahasa Jepang sebagai ekstrakulikurer (The Japan Foundation, 2017). 
Jika dilihat dari jumlah pembelajaran bahasa Jepang pada tingkat SD, menunjukan bahwa bahasa Jepang juga diminati anak SD. Meskipun dengan perbandingan pembelajar tingkat SD lebih sedikit dari pada tingkat atas. Pembelajaran bahasa Jepang di Indonesia sudah dilakukan di SD yang ada di Bali. Hal ini dibuktikan penelitian terdahulu yang dilakukan Mardani (2018) mengenai profil pembelajaran bahasa Jepang tingkat SD di Bali, diketahui bahwa pembelajaran bahasa Jepang sudah dilakukan oleh 11 SD yang ada di Bali. Namun dari studi pendahuluan yang dilakukan pada tanggal 7-9 Mei 2019, diketahui bahwa dari 11 SD tersebut 1 sekolah sudah tidak menerapkan pembelajan bahasa Jepang. Sehingga ada 10 SD di Bali yang masih menerapkan pembelajaran bahasa Jepang. Dari 10 SD tersebut, masing-masing sekolah memulai pengajaran bahasa Jepang pada jenjang kelas yang berbeda-beda.

Adapun 10 SD di Bali yang mengajarkan bahasa Jepang yaitu, SD Saraswati 1 Denpasar, SD Saraswati 2 Denpasar, SD Saraswati 3 Denpasar, SD Saraswati 4 Denpasar, SD Saraswati 5 Denpasar, SD Saraswati 6 Denpasar, SD Tunah Kasih Nusa Dua, SD Widiatmika, SD Saraswati Tabanan, dan SD Mutiara Singaraja. Berdasarkan data di atas menunjukan bahwa sudah semestinya pembelajaran bahasa Jepang pada tingkat SD menjadi perhatian bagi pihak penyelenggaran Pendidikan Bahasa Jepang di Indonesia.

Namun pada kenyataannya, pembelajaran bahasa Jepang pada tingkat SD belum mendapat perhatian dari pihak yang terkait penyelenggaraan Pendidikan Bahasa Jepang di Indonesia. Ini dibuktikan dari survei yang dilakukan The Japan Foundation 2017, diketahui bahwa pembelajaran bahasa Jepang yang diterapkan di Indonesia masih berfokus pada jenjang SMA/SMK (Mardani, dkk 2020). Hal ini menjadi permasalahan yang harus segera diatasi, karena melihat jumlah peminat bahasa Jepang pada tingkat SD tidak sedikit. Sehingga sangat diperlukan perhatian lebih lanjut terkait pembelajaran bahasa Jepang pada jenjang SD.

Pembelajaran pada jenjang SD sudah menggunakan Kurikulum 2013 Revisi yang dalam pembelajaran lebih menekankan proses dari pada hasil. Kurikulum 2013 revisi menuntut pada penekanan keterampilan abad 21 4C (Communication, Collaboration, Critical Thinking and Problem Solving, dan Creativity and Innovation), Penguatan Pendidikan Karakter (PPK), literasi, dan HOTS (Higher Order Thinking Skills) (Mulyasa, 2018). Hal ini menjadi tantangan tersendiri bagi guru pada abad ke-21, karena harus mengintegritaskan pembelajaran pada (4C), PPK, Literasi, dan HOTS agar proses pembelajaran sesuai dengan Kurikulum 2013 Revisi. Sehingga guru memerlukan RPP yang mampu mengimplementasikan keterampilan dari Kurikulum 2013 Revisi.

Bagi guru RPP menjadi hal mutlak yang harus dimiliki dalam melakukan proses pembelajaran, karena dengan RPP guru dapat melaksanakan pembelajaran di kelas dengan sistematis dan terarah agar dapat mengimplemtasikan kurikulum yang digunakan. Hal ini diperkuat oleh pernyataan dari Mulyasa (2018) yang menyatakan bahwa tugas utama guru adalah membuat RPP dengan menjabarkan silabus, agar dapat menerapkan pembelajaran sesuai dengan kurikulum secara optimal.

Selain itu, RPP yang dibuat tidak hanya harus sesuai dengan Kurikulum 2013 Revisi, tapi strategi pembelajaran yang digunakan harus sesuai dengan karakteristik anak SD. Namun pada kenyataannya, dalam penelitian terdahulu yang dilakukan terkait profil pembelajaran bahasa Jepang SD di Bali, diketahui bahwa hampir semua SD yang menerapkan pembelajaran bahasa Jepang yang menjadi objek penelitian masih menggunakan strategi yang sama seperti tingkat SMA (Mardani, 2018). Hal ini menjadi permasalahan tersendiri, karena perkembangan kognitif anak SD berbeda dengan siswa SMA.

Berdasarkan hasil angket dalam penelitian terdahulu yang dilakukan oleh Mardani, dkk (2020) mengenai pembelajaran bahasa Jepang berbasis Kurikulum 2013 Revisi pada tingkat SD di Bali, diketahui bahwa dari 10 SD di Bali yang mengajarkan bahasa Jepang 7 SD yang sudah menerapkan Kurikulum 2013 Revisi. Dari 11 responden guru, 64\% menyatakan sangat perlu dikembangkan RPP berbasis Kurikulum 2013 Revisi. 
Berdasarkan presentase kebutuhan tersebut, maka dikembangkan RPP tahap awal berbasis Kurikulum 2013 Revisi untuk SD. Pengembangan RPP ini penting untuk dilakukan karena dalam RPP ini memiliki keunggulan pada tahap kegiatan pembelajarannya yang memuat 4C, literasi, PPK, dan HOTS. Selain itu, startegi pembelajaran yang digunakan disesuikan dengan karakteristik anak SD yang lebih banyak memuat permaianan. Sehingga hal ini dapat membantu guru untuk mengimplementasikan proses kegiatan belajar yang sesuai dengan Kurikulum 2013 Revisi yang dianjurkan.

Penelitian sejenis pernah dilakukan oleh Ahmad (2015) mengenai pengembangan RPP untuk SMA. Penelitian ini bertujuan untuk mengembangkan RPP bahasa Inggris berbasis Kurikulum 2013. Model pengembangan dalam penelitian ini menggunakan model Brog \& Gall. Hasil dari penelitian ini, yaitu (1) RPP yang dikembangkan berbasis Kurikulum 2013 untuk pelajaran bahasa Inggris, (2) berdasarkan uji coba produk terhadap guru mendapatkan poin 95 dengan kategori sangat layak.

Perbedaan peneltian dari Ahmad (2015) dengan penelitian ini yaitu penelitian terdahulu mengembangkan RPP bahasa Inggris yang berbasis Kurikulum 2013 untuk SMA, sedangkan penelitian ini mengembangkan RPP tahap awal pembelajaran bahasa Jepang berbasis Kurikulum 2013 Revisi untuk SD. Kemudian penelitian terdahulu mengembangan RPP untuk SMA 18 Makassar, sedangkan penelitian ini mengembangan RPP untuk 10 SD di Bali.

Berdasarkan paparan tersebut, maka diperlukan sebuah RPP tahap awal berbasis standar proses Kurikulum 2013 Revisi yang sesuai untuk SD di Bali. Sehingga guru memiliki pedoman dalam melakukan proses belajar sesuai dengan Kurikulum 2013 Revisi dan memudahkan guru untuk melaksanakan proses mengajar. Selain itu, dengan RPP ini guru dapat melaksanakan strategi pembelajaran yang sesuai dengan karakteristik anak SD.

\section{Metode}

Penelitian ini merupakan penelitian dan pengembangan yang mengembangkan RPP tahap awal bahasa Jepang berbasis standar proses Kurikulum 2013 Revisi yang sesuai untuk sekolah dasar. Penelitian pengembangan ini menggunakan model pengembangan four-D dari Thiagarajan tahun 1974. Alasan memilih model 4D dalam penelitian ini adalah karena model 4D hanya terdiri dari empat tahap, dan hanya dengan empat tahapan model ini sudah kompleks, serta mencakup semua yang diperlukan dalam penyusunan rencana pelaksanaan pembelajaran. Tahapan dari model pengembangan four- $D$ dari Thiagarajan yang akan dipaparkan sebagai berikut.

Tahap pertama: define (pendefinisian), pada tahap ini kegiatan yang dilakukan yaitu menganalissi kebutuhan dalam perangkat pembelajaran yang dikembangkan. Untuk mengetahui permasalahan yang dihadapi, dilakukan penyebaran angket kepada guru bahasa Jepang di SD dan melakukan wawancara kepada siswa di SD di Bali yang mendapatkan bahasa Jepang. Dalam tahap ini ada lima langkah yang digunakan untuk kegiatan menganalis, yaitu

1. Front and analysis, pada tahap ini dilakukan analisis awal yang bertujuan untuk mengetahui masalah dasar apa yang dihadapi oleh guru. Sehingga untuk mengetahuai masalah yang dihadapi guru dilakukan pemberian angket kepada guru pengajar bahasa Jepang di sekolah dasar di Bali.

2. Learner analysis, pada tahap kedua ini dilakukan untuk mengetahui karakteristik yang dimiliki siswa. Untuk mendapatkan informasi pada tahap ini dilakukan dari wawancara terhadap siswa dan juga hasil angket dari guru mata pelajaran bahasa Jepang.

3. Taks analysis, dilakukan analisis dengan cara menentukan materi yang relevan, indikator pencapaian, dan tujuan pembelajaran dalam RPP untuk mengetahui keterampilan utama yang akan diperoleh siswa.

4. Concept analysis, pada tahap ini dilakukan cara menentuka strategi pembelajaran yang digunakan agar sesuai dengan materi dan karakteristik anak SD. 
5. Specifying analysis, merangkum hasil analisis dari task analysis dan consept analysis untuk menentukan tujuan akhir. Sehingga tujuan tersebut menjadi dasar dalam menyusun RPP.

Tahap kedua: design (perancangan), pada tahap ini sudah merancang dan membuat produk awal. Pada konteks pengembangan produk RPP ini dimulai dengan mengisi kolom identitas, mengkaji kompetensi dasar, mengkaji kompetensi inti, menentukan indikator pencapaian, merumuskan tujuan pembelajaran, mengidentifikasi materi pembelajaran, menentukan pendekatan dan metode, menentukan media pembelajaran, menentukan materi, menyusun langkah pembelajaran, dan menyusun penilaian.

Tahap ketiga: develop (pengembangan), tujuan dari tahap ini, yaitu dilakukannya tahap uji ahli perangkat pembelajaran dan perbaikan berdasarkan masukan dari uji ahli. Pada tahap ini meliputi dua tahap, yaitu;

1. Expert appraisal, pada tahap ini uji ahli yang dilakukan adalah uji ahli isi. Tahap pengumpulan data dalam uji ahli isi ini dilakukan dengan menggunakan angket, dan setelah dilakukan pengumpulan data berupa angket uji ahli isi dilanjutkan dengan dilakukan penyempurnaan produk sesuai saran yang diberikan.

2. Developmental testing, dilakukan kegiatan uji coba produk kepada guru untuk mengetahui respon guru terhadap produk yang dikembangkan. Uji coba yang dilakukan adalah uji coba terbatas. Uji coba terbatas ini hanya dilakukan kepada satu guru pengajar bahasa Jepang di SD yang ada di Bali.

Tahap keempat: disseminate (penyebaran), Pada tahap ini dilakukan penyebaran final. Produk yang sudah direvisi diimplementasikan pada sasaran sesungguhnya. Pada penelitian ini tahap empat tidak dilakukan mengingat keterbatasan waktu.

Dalam penelitian pengembangan, produk berupa RPP tahap awal berbasis standar proses Kurikulum 2013 Revisi untuk sekolah dasar di Bali di uji tingkat validitas dan keefektivannya dilakukan melalui uji ahli isi dan uji coba produk terbatas. Uji coba produk dilakukan untuk mengetahui kelayakan dari produk yang dikembangkan. Uji coba produk dalam pengembangan ini terdiri dari desain uji coba dan subjek uji coba. Hal ini dilakukan untuk memperoleh saran, pendapat dan penilaian terakit RPP yang dikembangkan. desain uji coba dalam pengembangan RPP tahap awal bahasa Jepang berbaisis Kurikulum 2013 Revisi ini menggunakan desain deskriptif yang diuji validitasnya. Sebelum produk ini layak atau tidak digunakan, maka dilakukan tahap uji ahli terlebih dahulu. Uji ahli produk yang dilakukan pada penelitian ini, yiatu uji ahli isi. Uji ahli isi ini dilakukan untuk memperoleh penilaian, saran, dan masukan dari produk yang dikembangkan. Selanjutnya uji coba produk dilakukan secara terbatas pada guru pengajar bahasa Jepang di SD di Bali untuk mengetahui respon guru. Istrumen yang digunakan berupa angket kombinasi untuk uji ahli produk dan uji coba produk. Uji coba yang dilakukan pada penelitian ini dilakukan secara terbatas. Uji coba terbatas ini dilakukan kepada satu guru pengajar bahasa Jepang di sekolah dasar. Uji coba produk terbatas ini dilakukan untuk mengetahui respon guru terkait RPP yang dikembangkan berbasis Kurikulum 2013 Revisi

Pada pengembangan ini dilakukan uji coba secara terbatas kepada guru pengajar bahasa Jepang di SD yang ada di Bali. Sehingga subjek uji coba dalam penelitian ini adalah guru pengajar bahasa Jepang di SD Mutiara Singaraja.

Jenis data yang digunakan dalam penelitian ini yaitu data kualitatif. Data kualitatif ini diperoleh dari hasil angket uji ahli isi dan uji coba produk yang berisi penilaian, saran, masukan, dan komentar. Data uji ahli isi diperoleh dari 2 dosen di Universitas Pendidikan Ganesha, sedangkan data uji coba produk diperoleh dari guru bahasa Jepang di SD Mutiara Singaraja. Data-data tersebut digunakan sebagai pedoman untuk merevisi produk yang dikembangkan.

Dalam penelitian ini menggunakan metode wawancara dan angket dalam pengumpulan data. Berikut akan dipaparkan metode pengumpulan data. 


\section{Wawancara}

Dalam penelitian ini menggunakan jenis wawancara terstruktur. Wawancara ini bertujuan untuk memperoleh informasi dari pertanyaan yang dibuat dan responden hanya menjawab sesuai dengan pertanyaan yang diajukan. Wawancara terstruktur ini dilakukan karena subjek wawancara adalah siswa SD, sehingga dengan melakukan wawancara ini, akan mempermudah siswa untuk menjawab pertanyaan sesuai yang pedoman wawancara.

Dalam penelitian ini wawancara dilakukan kepada siswa di 10 SD di Bali pada tanggal 7-9 Mei 2019 untuk memperoleh informasi terkait pembelajaran bahasa Jepang. Wawancara ini dilakukan secara acak kepada 3-5 siswa pada masing-masing sekolah. Sekolah yang dilakukan wawancara masing-masing 5 siswa yaitu di SD Saraswati 1 Denpasar, SD Saraswati 3 Denpasar, SD Saraswati 4 Denpasar, SD Tunas Kasih Nusadua, dan SD Mutiara Singaraja. Sekolah yang dilakukan wawancara masing-masing 4 siswa, yaitu di SD Saraswati 2 Denpasar, SD Saraswati 5 Denpasar, dan SD Saraswati 6 Denpasar. Sekolah yang dilakukan wawancara masing-masing 3 siswa, yaitu SD Widiatmika dan SD Saraswati Tabanan.

\section{Angket}

Dalam penelitian ini mengunakan jenis angket kombinasi. Angket ini diberikan kepada guru pengajar bahasa Jepang di 10 SD di Bali pada tanggal 7-9 Mei 2019. Angket ini digunakan untuk mengetahui informasi terkait informasi terkait strategi dan materi pembelajaran bahasa Jepang pada tingkat SD di Bali.

Selain itu, jenis angket kombinasi ini juga digunakan pada saat menganalisis uji ahli isi dan uji coba. Uji ahli isi dilakukan oleh 2 dosen di Universitas Pendidikan Ganesha pada tanggal 26 September 2019 untuk mengetahui kelayakan dari produk yang dikembangkan. Sedangkan uji coba dilakukan oleh guru pengajar bahasa Jepang di SD Mutiara Singaraja pada 24 Januari 2020 untuk mengetahui respon guru terkait produk yang dikembangkan.

Instrumen pengumpulan data pada penelitian ini dilakukan dengan pedoman wawancara dan angket. Berikut instrumen pengumpulan data yang dilakukan pada penelitian ini.

\section{Pedoman Wawancara}

Dalam proses pengumpulan data dilakukan wawancara kepada siswa secara acak kepada siswa 3-5 di 10 SD di Bali untuk memperoleh informasi terkait kegiatan mata pelajaran bahasa Jepang. Wawancara yang dilakukan dengan wawancara terstruktur, sehingga pedoman wawancara dibuat dengan tertrsuktur. Pedoman wawancara terdiri dari pertanyaan yang ingin ditanyakan, kemudian responden akan menjawab sesuai dengan pedoman wawancara.

\section{Lembar Angket}

Pada penelitian ini lembar angket digunakan untuk memperoleh nilai kelayakan pada uji ahli isi dan uji coba produk. Hal ini dilakukan untuk memperoleh informasi dari kelayakan produk yang telah dikembangkan. Lembar angket yang telah berisi bertanyaan tertulis terkait RPP yang sudah dikembangkan diberikan kepada uji ahli isi untuk diberikan penilaian, saran, dan masukan terkait kelayakan produk.

Setelah data dari ahli diperoleh, kemudian untuk melihat bobot masing-masing tanggapan dan menghitung skor reratanya dengan rumus sebagai berikut.

$$
\bar{x}=\frac{\Sigma x}{n}
$$

Keterangan: 


$$
\begin{array}{ll}
\overline{\mathrm{x}} & : \text { skor rata-rata } \\
\mathrm{n} & : \text { jumlah penilai } \\
\Sigma \mathrm{x} & : \text { skor total masing-masing }
\end{array}
$$

Setelah mendapatkan hasil skor dosen evaluator ahli, skor kemudian dipersentasekan menggunakan rumus sebagai berikut.

$$
\text { Hasil }=\frac{\text { total skoryang diperoleh }}{\text { skor } \text { maksimum }} \times 100 \%
$$

Dengan kategori kelayakan berdasarkan kriteria sebagai berikut. (Arikunto, 2009:35)

Tabel 1 Kriteria Kelayakan

\begin{tabular}{c|c} 
Skor dalam persen & Kategori Kelayakan \\
$<21 \%$ & Sangat Tidak Layak \\
$21-40 \%$ & Tidak Layak \\
$41-60 \%$ & Cukup Layak \\
$61-80 \%$ & Layak \\
$81-100 \%$ & Sangat Layak \\
\hline
\end{tabular}

\section{Hasil dan Pembahasan}

Perangkat pembelajaran yang dikembangkan dalam penelitian ini adalah RPP tahap awal untuk SD di Bali. Penelitian ini dilakukan karena di SD belum tersedianya RPP yang sesuai dengan Kurikulum 2013 Revisi. Hal ini menyebabkan guru bahasa Jepang di SD belum dapat menerapkan tuntutan dari keterampilan abad-21 (4C), literasi, PPK, dan HOTS. Sehingga dikembangkan RPP tahap awal bahasa Jepang berbasis standar proses Kurikulum 2013 Revisi untuk SD di Bali.

RPP yang dikembangkan ini terdiri dari 15 bab yaitu dari bab 1 sampai bab 15. Dalam RPP ini disusun sesuai dengan tahapan pembelajaran bahasa Jepang dasar, yaitu dounyuu, kihon renshuu, dan ouyou renshuu. Sehingga dalam proses pembelajarannya akan melalui proses wakaru (memahami), oboeru (mengingat), dan tsukau (memakai). Selain itu, strategi pembelajaran yang digunakan dalam RPP ini disesuaikan dengan karakteristik anak SD dan sesuai dengan strategi pembelajaran yang digunakan oleh guru pengajar bahasa Jepang di SD melalui angket yang telah diisi guru.

RPP ini juga disusun sesuai dengan tuntutan Kurikulum 2013 Revisi, yang dalam pengimplementasiannya menuntut keterampilan abad 21(4C), PPK, Literasi, dan HOTS. Sehingga langkah-lagkah pembelajran RPP ini dibuat agar dapat mengimplemtasikan 4 tuntutan keterampilan dari Kurikulum 2013 Revisi. Selanjutnya, penilaian yang dilakukan dalam RPP ini ada 3 penilaian, yaitu penilaian sikap, penilaian pengetahuan, dan penilaian keterampilan.

RPP memliki peranan penting sebagai pedoman bagi seorang guru dalam melakukan pembelajaran di kelas agar pembelajaran dikelas menjadi sistematis dan terarah. Sesuai dengan fungsi sebagai acuan bagi guru melaksanakan proses pembelajaran yang dilakukan, sehingga proses belajar mengajar menjadi sistematis dan dapat berjalan dengan efektif dan efesien. Selain itu, dengan adanya RPP guru dapat membuat rancangan pembelajaran yang dapat mengimplementasikan tututan Kurikulum 2013 Revisi. Berdasarkan faktor itu, maka dikembangkan RPP tahap awal pembelajaran bahasa Jepang berbasis Kurikulum 2013 Revisi untuk SD di Bali.

Pada pengembangan RPP ini dilakukan dengan menggunakan model pengembangan four-D yang dikembangkan oleh Thiagarajan 1974. Dalam model pengembangan four-D yang digunakan untuk mengembangkan produk ini hanya sampai pada tahap yang ketiga yaitu, define, design, dan develop.

Pada tahap pertama yaitu mendefisikan masalah dan menganalisis kebutuhan. Pada tahap ini dilakukan dengan cara melakukan wawancara kepada siswa dan penyebaran angket kepada guru pengajar bahasa Jepang di SD. Penyebaran angket dilakukan pada 10 
SD di Bali. Dari 10 SD di Bali, enam sekolah yang belum menggunakan RPP yang sesui dengan Kurikulum 2013 Revisi. Empat sekolah yang sudah menggunakan RPP yang dikembangkan masing-masing oleh masing-masing guru. Namun dalam RPP yang dikembangkan belum memuat keterampilan 4C dan HOTS yang ada dalam Kurikulum 2013 Revisi.

Berdasarkan hasil angket yang diberikan kepada guru pengajar bahasa Jepang di SD, masalah yang temukan yaitu terkait belum tersedia RPP yang sesui dengan kurikulum 2013 revisi. Sehingga belum dapat menerapkan tuntutan dari Kurikulum 2013 Revisi terkait keterampilan abad 21 (4C), PPK, literasi, dan HOTS. Oleh sebab itu diperlukan dikembangkannya RPP tahap awal bahasa Jepang berbasis standar proses Kurikulum 2013 Revisi untuk SD.

Tahap kedua yaitu perancangan produk awal RPP. Pada tahap ini dilakukan setelah mendapatkan hasil dari analisis kebutuhan pada tahap sebelumnya. Pada tahap ini produk RPP mulai dirancang seperti pemilihan metode, strategi dan media yang tepat digunakan sesuai dengan materi setiap bab. Dalam menyusun langkah-langkah pembelajaran yang digunakan dalam RPP ini, terkait dengan pemilihan metode dan strategi pembelajaran harus disesuaikan dengan karakterisitik anak SD. Sehingga dapat menciptakan suasana belajar yang menyenangkan dengan membuat langkah pembelajaran menggunakan permainan, lagu, video, gambar dan media lainnya. Selain itu, RPP ini juga dilengkapi dengan intrumen penilaian untuk mempermudah melakukan penilaian.

Adapun produk RPP yang dikembangkan ini terdiri dari bab 1 sampai bab 15 yang memuat tuntutan kurikulum 2013, yaitu bab 1 aisatsu, bab 2 jikoshokai, bab 3 suuji 1-20, bab 4 iro, bab 5 youbi, bab 6 karada, bab 7 watashi no kazoku, bab 8 diah san no kazoku, bab 9 suuji 21-100, bab 10 nenrei, bab 11 tanjoubi, bab 12 jikan,bab 13 norimono, bab 14 kyoushitsu, dan bab 15 gakkou.

RPP ini dikembangkan sesuai dengan komponen RPP yang berbasis standar proses Kurikulum 2013 Revisi, seperti mengisi kolom identitas (nama sekolah, mata pelajaran, kelas/semester, materi pokok, dan alokasi waktu), kompetensi dasar, kompetensi inti, Indikator pencapaian, tujuan pembelajaran, materi pembelajaran, penentuan pendekatan dan metode, media pembelajaran, sumber, langkah pembelajaran, dan penilaian.

Setiap bab dalam RPP yang dikembangkan disesuaikan dengan tuntutan kurikulum 2013 yang memuat keterampilan abad 21 (4C), PPK, literas, dan HOTS, yang merupakan salah satu ciri khas dari RPP yang dikembangkan ini. Keempat keterampilan pada Kurikulum 2013 Revisi tersebut sudah termuat pada masing-masing bab RPP yang dikembangkan untuk memudahkan guru untuk menerapkan tuntutan Kurikulum 2013 Revisi di dalam kelas. Berikut contoh pengimplementasian tuntutan tuntutan Kurikulum 2013 Revisi dalam RPP ini, yaitu yang pertama PPK (Penguatan Pendidikan Karakter) yang dimunculkan dalam RPP ini seperti yaitu bekerja sama, komunikatif, santun dan percaya diri. Keterampilan kedua yaitu literasi. Literasi tidak hanya melalui media buku namun juga melalui media lainnya seperti mengamati gambar dll.

Keterampilan yang ketiga yaitu 4C dalam RPP ini dapat diaplikasikan melalui kegiatan pembelajaran. Seperti salah satu contoh kegiatan pembelajaran yang mengimplementasikan keterampilan 4C dalam RPP ini yaitu peserta didik secara berkelompok diajak untuk mewarnai sebuah gambar yang telah diberikan keterangan warna dalam bahasa Jepang. Sehingga sebelum siswa memberikan warna pada gambar, siswa terlebih dahulu harus memikirkan warna apa yang tepat sesuai dengan keterangan warna dalam bahasa Jepang yang diberikan. Kemudian siswa dilatih untuk berkerjasama dalam kelompok untuk menyelesaikan masalah secara bersama. Siswa juga harus mengomunikasikan terkiat gambar yang telah diwarnai kepada teman-temannya. Sehingga dengan ini siswa mampu untuk berpikir kritis, berkerja sama, dan berkomunikasi untuk mampu menyesaikan masalah yang diberikan.

Selanjutnya keterampilan yang keempat yaitu HOTS. Pembelajaran yang mengimplementasikan HOTS ini menuntut siswa untuk berpikir tinggi. HOTS dalam RPP ini diimplementasikan melalui kegiatan pembelajaran. Seperti salah satu contoh kegiatan 
pembelajaran yang mengimplementasikan HOTS dalam RPP ini yaitu dalam pembelajaran kazoku. Dalam pembelajaran kazoku siswa sudah memahami terkait haha, chichi dan anggota keluarga lainnya. Dalam artian ibu dalam bahasa Jepang yang diketahui siswa adalah haha. Namun dalam pembelajaran Ayu san no Kazoku, okaasan juga memiliki arti ibu. Dalam konteks ini guru memberikan pertanyaan sederhana kepada peserta didik agar dapat menuntut siswa untuk berpikir tinggi mengenai permasalahan haha dan okaasan yang memiliki arti yang sama yaitu ibu. Sehingga dengan memberikan pertanyaan siswa dapat menganalisa infomasi agar siswa terlatih untuk mempertanyakan materi dan melatih peserta didik untuk mememukan berbagai opsi. Setelah siswa menganalisa, siswa akan mampu untuk mengevaluasi (menghasilkan informasi baru) sesuai dengan analisa dari permasalahan yang diberikan. Sehingga dengan ini siswa akan terbiasa untuk berpikir tinggi.

Tahap ketiga yaitu tahap pengembangan. Pada tahap ini dilakukan dengan lanjut mengembangkan produk setelah tahap kedua dilakukan. Tahap ini juga dilakukan uji ahli isi dan uji coba produk. Uji ahli isi ini dilakukan untuk mengetahui kelayakan produk yang dibuat sebelum melakukan uji coba produk. Uji ahli produk dilakukan kepada 2 dosen ahli Universitas Pendidikan Ganesha. Setelah melakukan uji ahli isi, dilakukan revisi produk sesuai dengan saran dan komentar dari ahli. Setelah tahap revisi produk selesai, dilakukan uji coba produk terhadap satu guru pengajar bahasa Jepang di SD, yaitu di SD Mutiara Sinagaraja.

Berikut hasil penilaian yang dilakukan oleh uji ahli isi dan uji coba produk. Uji ahli isi RPP tahap awal. Ada beberapa komponen aspek penilaian uji ahli isi pada RPP ini meliputi: komponen dalam RPP sudah sesuai dengan Kurikulum 2013 Revisi yang memunculkan keterampilan 4C, HOTS, PPK, dan literasi, kejelasan kompetensi dasar, kesesuaian indikator dengan kompetensi dasar, kesesuaian indikator pencapaian dengan materi, kesesuaian materi dengan tujuan pembelajaran, ketepatan memilih media pembelajaran dengan materi, pemanfaatan teknologi sesuai materi pembelajaran, pemilihan model pembelajaran yang sesuai dengan 4C, kejelasan langkah pembelajaran yang menuntut terbentuknya keterampilan abad 21, ketepatan penilaian sesuai dengan tujuan pembelajaran dan sesaui dengan Kurikulum 2013 Revisi, penggunaan bahasa jelas dan logis, dan kelengkapan instrumen penilaian.

Berdasarkan penilaian yang sudah diberikan oleh ahli isi, kompenen RPP sudah sesuai dengan Kurikulum 2013 Revisi, dalam RPP sudah memunculkan keterampilan 4C, HOTS, PPK, dan literasi, Indikator pencapaian sudah sesuai dengan kompetensi dasar dan materi pembelajaran. Selanjutnya tujuan pembelajaran sudah sesuai dengan kompetensi dasar. Namun dalam komentar yang diberikan jumlah tujuan pembelajaran yang dibuat harus sama dengan indikator pencapaian. Sehingga dibuat tujuan pembelajaran dengan jumlah yang sama sesui dengan indikator pencapaian. Dalam pemilihan media pembelajaran digunakan media yang memanfaatkan teknologi yang sesuai dengan materi. Langkahlangkah pembelajaran sudah menuntut terbentuknya keterampilan abad 21, literasi, dan PPK. Kemudian instrumen penilaian yang dibuat sudah lengkap sesuai dengan Kurikulum 2013 Revisi. Dari penilaian yang dilakukan oleh uji ahli isi dapat disimpulkan RPP sudah sesuai dan layak digunakan.

Setelah dilakukan revisi yang sesuai dengan masukan dari uji ahli isi, lakukan uji coba produk pada guru pengajar bahasa Jepang di SD Mutiara Singaraja. Adapun komponen penilaian uji coba produk pada RPP ini meliputi: komponen dalam RPP sudah sesuai dengan Kurikulum 2013 Revisi yang memunculkan keterampilan 4C, HOTS, PPK, dan literasi, kejelasan kompetensi dasar, kesesuaian indikator dengan kompetensi dasar, kesesuaian indikator pencapaian dengan materi, kesesuaian materi dengan tujuan pembelajaran, ketepatan memilih media pembelajaran dengan materi, pemanfaatan teknologi sesuai materi pembelajaran, pemilihan model pembelajaran yang sesuai dengan 4C, kejelasan langkah pembelajaran yang menuntut terbentuknya keterampilan abad 21 , ketepatan penilaian sesuai dengan tujuan pembelajaran dan sesaui dengan Kurikulum 2013 Revisi, penggunaan bahasa jelas dan logis, dan kelengkapan instrumen penilaian. 
Dari penilaian uji coba produk yang dilakukan mendapatkan hasil bahwa semua komponen dalam RPP sudah sesui dengan Kurikulum 2013 Revisi yang memuat keterampilan 4C, HOTS, PPK, dan literasi. Dalam pengunaan bahasa dalam RPP sudah jelas, logis, dan mudah dipahami. Dari keseluruhan penilaian oleh guru pengajar bahasa Jepang di SD Mutiara Singaraja, RPP ini sudah sesui dan layak digunakan. Berikut merupakan rata-rata perolehan dari hasil penilaian uji ahli dan uji coba RPP.

Tabel 2. Hasil Penilaian Secara Keseluruhan

\begin{tabular}{c|c|c}
\hline Evaluator & Penilaian & Kategori \\
Uji ahli isi & $96,25 \%$ & Sangat layak \\
Uji coba & $84.44 \%$ & Sangat layak \\
\hline
\end{tabular}

Berdasarkan hasil intrumen penilaian dari uji ahli isi mendapatkan poin $96.25 \%$ sedangkan pada uji coba mendapatkan poin $84.44 \%$ dengan kategori sangat layak. Sehingga dapat disimpulkan bahwa RPP tahap awal berbasis standar proses Kurikulum 2013 Revisi sangat layak untuk digunakan. Selain itu, RPP ini juga memiliki keunggulan sebagai berikut; (1) Dalam RPP yang dikembangkan ini memuat keterampilan abad-21 (4C), literasi, PPK, dan HOTS. (2) Pemilihan strategi pembelajaran yang dicantumkan dalam RPP ini disesuaikan dengan karakteristik anak SD. (3) Kata perintah sederhana dalam bahasa Jepang juga dicantumkan pada masing-masing bab dalam RPP ini.

\section{Simpulan dan Saran}

Penelitian ini dikembangkan untuk memenuhi kebutuhan terkait pedoman dan acuan mengajar bagi guru pengajar bahasa Jepang tingkat SD. Hal ini dikarenakan dalam hasil dari analisis kebutuhan yang dilakukan, masalah yang dihadapi guru adalah belum adanya RPP yang sesuai dengan standar proses Kurikulum 2013 Revisi. Sehingga belum dapat mengimplementasikan tuntutan dari Kurikulum 2013 Revisi. Penelitian ini bertujuan untuk menghasilkan produk berupa rencana pelaksanaan pembelajaran berbasis Kurikulum 2013 Revisi yang sesuai untuk SD. Dengan dikembangkannya RPP ini dapat membantu guru dalam mempersiapkan pembelajaran yang berbasis Kurikulum 2013 Revisi.

Produk yang dikembangkan merupakan RPP tahap awal bahasa Jepang berbasis standar proses Kurikulum 2013 Revisi yang sesuai untuk SD. RPP yang dikembangkan sudah berisi keterampilan yang dituntut dalam mengimplementasikan Kurikulum 2013 Revisi yaitu keterampilan abad $21(4 \mathrm{C})$, literasi, PPK, dan HOTS. Selain itu pemilihan metode dan strategi pembelajaran disesuikan dengan karakteristik anak SD.

RPP ini dikembangkan menggunakan model pengembangan four-D yang dikembangkan oleh Thiagarajan 1974 yang sudah dimodifikasi agar sesuai dengan kebutuhan pengembangan. Model four-D dari Thiagarajan 1974 yang sudah dimodifikasi ini menjadi 3 tahapan, yaitu define, design, dan develop.

Untuk mengetahui kelayakan dari RPP yang dibuat dilakukan uji ahli terhadap 2 dosen dari Universitas Pendidikan Ganesha. Hasil dari rekapitulasi instrumen penilaian uji ahli isi mendapatkan hasil keseluruhannya yaitu 96,25\% dengan kategori sangat layak.Kemudian dilakukan revisi produk sesuai dengan saran dan komentar dari ahli. Setelah revisi produk, tahap selanjutnya dilakukan uji coba secara terbatas. Produk diujicobakan kepada 1 guru pengajar bahasa Jepang di SD Mutiara Singaraja. Hasil dari rekapitulasi instrumen penilaian uji coba mendapatkan hasil keseluruhannya yaitu $84.44 \%$ dengan kategori sangat layak.

Berdasarkan simpulan diatas, dapat disarankan beberapa hal sebagai berikut.

1. Bagi guru pengajar bahasa Jepang tingkat SD di Bali

Dengan dikembangkannya RPP ini, guru dapat menggunakan dalam mengajar sebagai acuan untuk melakukan pembelajaran yang berbasis standar proses Kurikulum 2013 Revisi di dalam kelas. Sehingga guru dapat mengimplementasikan keterampilan abad 21 (4C), literasi, PPK, dan HOTS.

2. Bagi Peneliti Lain 
Bagi peneliti/mahasiswa disarankan agar mengembangkan produk RPP pembelajaran bahasa Jepang untuk SD di Bali yang memuat lebih banyak permainan agar pembelajaran di kelas lebih menyenangkan. Kemudian, disarankan juga untuk mengembangkan RPP pembelajaran bahasa Jepang untuk SD sampai pada tahap disseminate (penyebaran), karena pada penelitian ini tahap disseminate (penyebaran) tidak dilakukan karena keterbatasan waktu.

\section{Daftar Pustaka}

Ahmad, Djuwairiah. 2015. Developing English Lesson Plans For The First Year Student of SMA 18 Makassar Based on the 2013 Curriculum. Eternal. Volume 1, nomor 2 (hlm187-200).

Arikunto, Suharsimi, dan Safrudidin, A.J, Cepi. 2009. Evaluasi Program Pendidikan Pedoman Teoritis Praktis Bagi Mahasiswa dan Praktisi Pendidikan. Jakarta: Bumi Aksara.

Japan Foundation. 2017. "Survey report on Japanese language education abroad 2015". Tersedia pada www.jpf.go.jp/e/project/japanese/survey/result/survey15.html. Diakses pada 2 Juni 2019.

Mardani, DMS. 2018. Profil Pembelajaran Bahasa Jepang pada Jenjang Sekolah Dasar di Bali. Laporan penelitian tidak diterbitkan.

Mardani,D.M.S.,Sadyana,I.W.,\& Adnyani, L.D.S. 2020. Laerning Japanese Language Based on 2013 Curriculum at Elementary School in Bali. Proceedings of the $3^{\text {rd }}$ Internasional Conference on Innovative Research Across Disciplines (ICIRAD,2019), 246-251.

Mulyasa, E. 2018. Implementasi Kurikulum 2013 Revisi Dalam Era Revolusi Industri 4.0. Jakarta:Bumi Aksara.

Thiagarajan, S.,Semmel, D., Semmel, M. 1974. "Instructional Development For

Training Teacher of Exceptional Children" Tersedia pada

http://files.eric.ed.gov/fulltext/ED090725.pdf Diakses pada 06 Agustus 2019 